\title{
Characterization of Five Meloidogyne incognita Effectors Associated with PsoRPM3
}

\author{
Wenjiang $\mathrm{Pu}^{\dagger}{ }^{\dagger}$, Kun Xiao ${ }^{\dagger}$, Sifang Luo, Haifeng Zhu ${ }^{\circledR}$, Zizhen Yuan, Chaoyuan Gao and Jianfang Hu *
}

check for updates

Citation: Pu, W.; Xiao, K.; Luo, S.; Zhu, H.; Yuan, Z.; Gao, C.; Hu, J. Characterization of Five Meloidogyne incognita Effectors Associated with PsoRPM3. Int. J. Mol. Sci. 2022, 23, 1498. https://doi.org/10.3390/ ijms23031498

Academic Editor: Massimo Maffei

Received: 2 December 2021

Accepted: 22 January 2022

Published: 28 January 2022

Publisher's Note: MDPI stays neutral with regard to jurisdictional claims in published maps and institutional affiliations.

Copyright: (C) 2022 by the authors. Licensee MDPI, Basel, Switzerland. This article is an open access article distributed under the terms and conditions of the Creative Commons Attribution (CC BY) license (https:// creativecommons.org/licenses/by/ $4.0 /)$.

\author{
Laboratory of Fruit Physiology and Molecular Biology, China Agricultural University, Beijing 100193, China; \\ puwj07@outlook.com (W.P.); xiaokun201@outlook.com (K.X.); Sifang.Luo@outlook.com (S.L.); \\ zhf51@outlook.com (H.Z.); yzznbst@outlook.com (Z.Y.); cristianogao7@outlook.com (C.G.) \\ * Correspondence: hujf@cau.edu.cn \\ + These authors contributed equally to this work.
}

\begin{abstract}
Root-knot nematodes (RKNs) are devastating parasites that invade thousands of plants. In this study, five RKN effectors, which might interact with Prunus sogdiana resistance protein PsoRPM3, were screened and identified. In situ hybridisation results showed that MiCal, MiGST_N_4, MiEFh and MiACPS are expressed in the subventral oesophageal glands (SvG), and MiTSPc hybridization signals are found in the dorsal esophageal gland (DG) of Meloidogyne incognita in the pre-J2. RT-qPCR data indicated that the expression of MiCal, MiGST_N_4, MiEFh, and MiACPS genes are highly expressed in M. incognita of pra-J2 and J3/J4 stages. The expression of MiTSPc increased significantly in the female stage of $M$. incognita. Moreover, all effectors found in this study localize in the cytoplasm and nucleus when transiently expressed in plant cells. In addition, MiGST_N_4, MiEFh, MiACPS and MiTSPc can elicit the ROS burst and strong hypersensitive response (HR), as well as significant ion leakage. Our data suggest that MiGST_N_4, MiEFh, MiACPS and MiTSPc effectors may be involved in triggering the immune response of the host plant.
\end{abstract}

Keywords: Xinjiang wild myrobalan (Prunus sogdiana); Meloidogyne incognita; resistance; effector; function

\section{Introduction}

Root-knot nematodes (RKNs; Meloidogyne spp.) are among the biggest threats to agricultural production around the world, causing over $\$ 80$ billion of losses annually [1,2]. Tremendous numbers of crops and trees are seriously invaded by root-knot nematodes [3-5]. RKNs infect the roots of crops and hinder the absorption of water and nutrients, leading to retardation and reduction in growth and development, resulting in a decline in yield and quality [6]. During parasitism, root-knot nematodes deliver nematode secretions (effectors) to plant cells via their stylets, suppressing plant defenses and inducing and/or maintaining feeding sites, i.e., the giant cells (GCs) [7]. Multinucleated cells developed by giant cells through intranuclear replication are the only source of nutrients for the growth and development of root-knot nematodes $[2,8,9]$. The development of nematodes from eggs to adults requires several different effectors to ensure their parasitism and life cycle in the host [10]. Currently, several nematode effectors have been identified by proteomic analysis, transcriptome and genome sequencing, as well as bioinformatics approaches [11-13]. However, the function of most effectors remains unclear. The function for many effectors has still not been elucidated.

Recent studies have shown that when RKNs penetrate and migrate into the root, they secrete effectors related to degradation or modification of the cell wall [14,15]. In addition, another important role for effectors is to promote the formation of feeding sites and giant cell to obtain adequate nutrient supply [16]. Therefore, to favor nutrient supply required for growth, RKNs secrete effectors to hijack the host's development and metabolism [17,18]. In the parasitic stage, effectors that inhibit plant immune responses to against plant defense responses or to protect nematode feeding cells are secreted by RKNs [19-21]. In addition, 
some effectors can help RKNs evade the attack of the plant immune system [22]. Therefore, the most important function of effectors is to suppress the host immune response. The different stages of root-knot nematode infection, such as initiating invasion, establishing feeding sites and inducing giant cell formation, require a large number of functional effectors $[23,24]$. However, it is still unclear which functional effectors are required by nematodes at specific times in different parasitic stages and in different tissue cells.

In Meloidogyne incognita, the effectors Mi-gsts-1, MiISE5, Misp12, and MiMsp40 are specifically expressed during the period of invasion and act in critical roles to overcome host defense responses and promote parasitism [25-28]. The M. incognita effector MiEFF18 can interact with essential components of the spliceosome SmD1, a complex involved in pre-mRNA splicing and alternative splicing in host plants. MiEFF18 modulates SmD1 to facilitate giant cell formation [29]. Effector MiEFF1 targets cytosolic glyceraldehyde-3phosphate dehydrogenases (GAPCs) that are induced in giant cells, and their nonmetabolic functions are required for root-knot nematode infection [30]. In addition, some M. incognita effectors can promote relative invasion and parasitism by specifically interfering with functional proteins involved in plant defence, such as the effectors MiMIF-2, MiISE6, and Minc17998 [31-33]. These studies have revealed the functions of some nematode effectors and indicated complex interactions between nematodes and host plants.

In plant-pathogen interactions, the famous ' $\mathrm{Z}$ ' model has accurately interpreted changes in the host defensive response [34,35]. According to this model, plants have evolved two layers of immunity: PAMP-triggered immunity (PTI), and effector-triggered immunity (ETI). During both PTI and ETI, plants rapidly produce large amounts of reactive oxygen species (ROS), an important signaling component in metabolic and stress responses in plants [36-39]. ROS production has been considered as one of early events of plant defense signaling $[40,41]$. Another effective strategy against the pathogen is known as HR, which generally occurs at the infection sites [42,43]. Plant resistance genes also play an important role in this process. Currently, some resistance genes have been reported such as $H 1$, resisting potato cyst-nematodes in potatoes, $\mathrm{Hs}{ }^{\text {pro-1 }}$ against Heterodera schachtii in sugar beet, $M i-1$ resisting $M$. incognita in tomato, and Ma resisting $M$. incognita in French cherry plum. [44-47]. However, an exact molecular model of nematode-plant interactions regulating PTI and ETI has not been established. Recently, research has clarified that ROS accumulation induced by PAMP contributes to enhancing the intensity of ETI and HR cell death [38]. In turn, sustained ROS induced by ETI can trigger a strong PTI-ROS burst [48].

Previously, we cloned and identified an NBS-LRR-type disease resistance gene PSoRPM3 from the RKNs-resistant plant Prunus sogdiana [49]. Here, 17 nematode effector candidates (Supplementary Table S1), which have the potential to target PsoRPM3 and influence plant resistance, were obtained by performing immunoprecipitation (IP) and liquid chromatography-tandem mass spectrometry (LC-MS) analysis in P. sogdiana. Five M. incognita effector proteins were selected to clarify the character and function in the 17 candidate nematode effector proteins. In situ hybridization was performed to analyze the spatial expression of these effectors in $M$. incognita. The developmental expression pattern of these effector genes was analyzed by RT-qPCR. Agrobacterium-mediated transient expression in disease-resistant tobacco showed that four effector proteins can induce a burst of ROS and HR. Consistent with the visual observations, the four effector proteins significantly increased ion leakage levels compared to control. Our data preliminarily determined the functions of the four effectors from M. incognita.

\section{Results}

\subsection{Five Candidate Effectors: Gene Amplification and Sequence Analysis}

We previously reported an RKN resistance gene, PsoRPM3, derived from $P$. sogdiana [49]. Immunoprecipitation (IP) combined with liquid chromatography coupled with a tandem mass spectrometry (LC-MS) assay was performed to screen for its $M$. incognita interactors (Supplementary Table S1). Six effectors (Minc3s00127g05433, scaffold166774_cov71.g22242, Minc3s00081g03887, Minc3s00642g15511, Minc3s01334g22880, 
and Minc3s07235g40885) were obtained from M. incognita (Figure 1A). Previous research reported that the molecular weight of effectors that can trigger plant immunity is generally smaller than the disease-resistance protein [50,51]. The molecular weight of the effector Minc3s07235g40885 obtained via IP and LC-MS is 179.48KD (Figure 1A), which is bigger than PsoRPM3 (107.490 KD). Therefore, Minc3s00127g05433, scaffold166774_cov71.g22242, Minc3s00081g03887, Minc3s00642g15511, and Minc3s01334g22880, but excluding Minc3s07235g40885, were cloned in M. incognita and their characters analyzed. The results revealed that Minc3s00127g05433 cDNA encoded a 416 amino acid protein which contains two Calreticulin domains and a coiled-coil region, with a predicted molecular size of $46.35 \mathrm{kDa}$ that consisted of an N-terminal signal peptide of 22 amino acids, named MiCal in this study. Scaffold166774_cov71.g22242 has 414 aa (amino acids) containing the GST_N_4 domain and an unknown (low complexity) region at position 58-147 aa and 247-296 aa, respectively, with an N-terminal signal peptide of 18 amino acids and was named MiGST_N_4. Minc3s00081g03887 cDNA encodes a 396 amino acid protein with a predicted 22 amino acid N-terminal signal peptide for secretion and a Tryp_SPc domain, named MiTSPc, containing the predicted bacterial Ig-like domain 1 (1-6 aa) and TRYPSIN_DOM Serine proteases (55-329 aa) motif. The open reading frame (ORF) of Minc3s01334g22880 contains 513 nucleotides, encoding a protein of 171 amino acids including five EFh domains, named MiEFh. The protein sequence of Minc3s01334g22880 contains SCOP: d1qr0a2s and ACPS domain, named MiACPS. Minc3s01334g22880 and Minc3s07235g40885 do not have signal peptides at the N-terminus (Figure 1B).

(A)

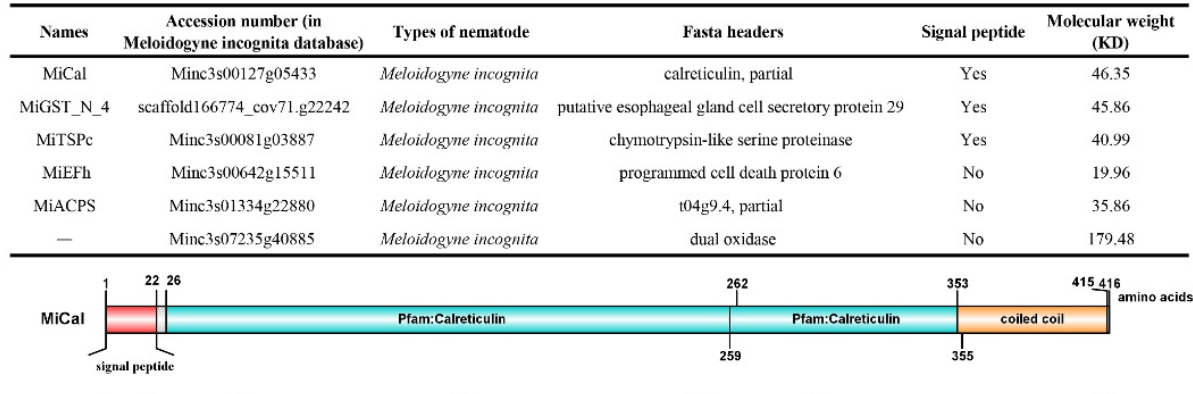
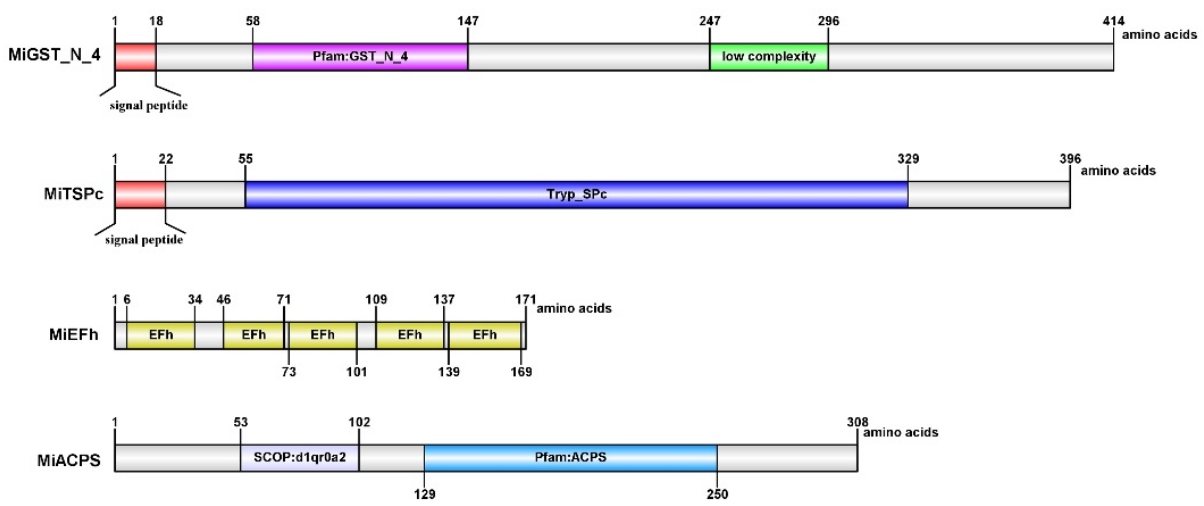

Figure 1. (A) Effector proteins from Meloidogyne incognita obtained by immunoprecipitation (IP) combined with liquid chromatography coupled with a tandem mass spectrometry (LC-MS) assay, showing their accession number in the M. incognita database, signal peptide status and protein molecular weights. (B) The characteristics of the five effectors of M. incognita.

\subsection{In Situ Hybridization in Pre-Parasitic Second-Stage Juveniles (Pre-J2) and Localization Analysis of Effectors}

To investigate the localization of effectors in $M$. incognita, in situ hybridization assays were performed. The specificity of all probe synthesis primers was detected by agarose gel electrophoresis (Supplementary Figure S1). A synthesized antisense strand probe and sense strand probe were used for in situ hybridization. The results showed that digoxigenin- 
labeled single-strand antisense cDNA probe of MiCal, MiGST_N_4, MiEFh, and MiACPS specifically hybridized in the subventral oesophageal glands (SvG) of pre-J2 of M. incognita (Figure 2A-D), whereas the MiTSPc transcripts were specifically expressed in the DG of pre-J2 of M. incognita (Figure 2E). As a negative control for the hybridization, a sense probe against effector was used, which did not induce a signal (Figure 2a-e).
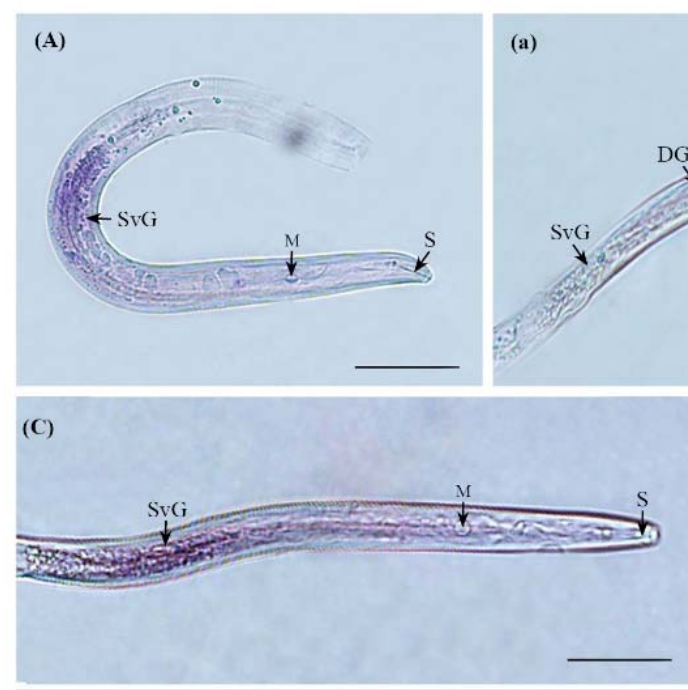

(c)

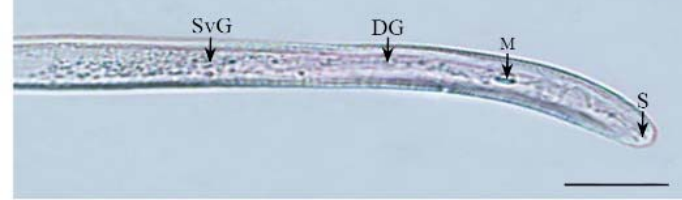

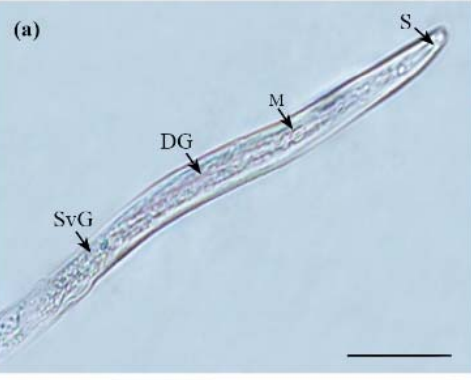

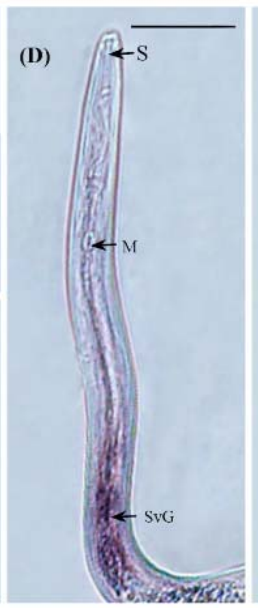

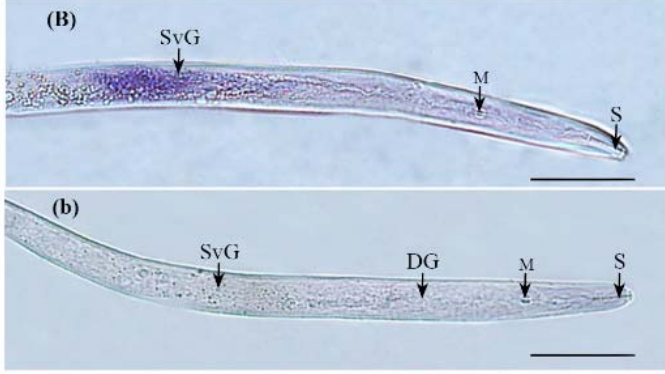

(d)
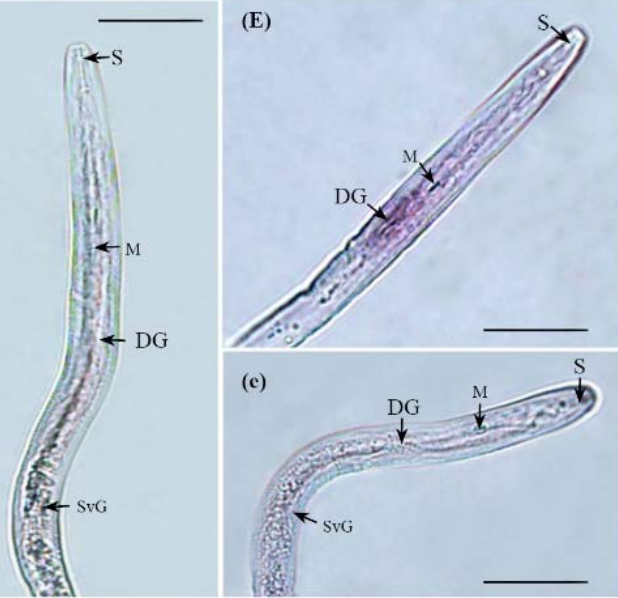

Figure 2. In situ hybridization of pre-J2 of M. incognita. (A-E) indicate the location of secretion detected by MiCal, MiGST_N_4, MiEFh, MiACPS, and MiTSPc antisense probes in second instar larval tissues of M. incognita, respectively. (a-e) indicate the detection of secretion location by MiCal, MiGST_N_4, MiEFh, MiACPS, and MiTSPc sense probes, respectively. Hybridization signals for all effectors were observed at the same secretory sites in at least 3-5 nematodes, and we showed one of the nematodes with hybridization signals for all effectors. Subventral oesophageal glands (SvG) and dorsal esophageal gland (DG), metacorpus (M), and stylet (S) are indicated with arrows. Scale bars, $50 \mu \mathrm{m}$.

\subsection{All Effectors Localize in the Nucleus and Cytoplasm when Expressed in Nicotiana benthamiana Cells}

Most nematode effectors are delivered into a host cell and localized to specific subcellular compartments to perform the distinct activity [52]. The online analysis revealed that MiTSPc contains a putative nuclear localization signal, while MiCal, MiGST_N_4, MiEFh, and MiACPS do not. To verify subcellular localization, the expression construct of 35S: $\mathrm{MiCal}^{\Delta S P}:$ GFP, 35S: MiGST_N_4${ }^{\Delta S P}:$ GFP, 35S: MiTSPc ${ }^{\Delta S P}:$ GFP, 35S: MiEFh: GFP, and 35S: MiACPS: GFP were transformed into Agrobacterium tumefaciens GV3101 strain and transiently expressed in leaf epidermal cells of $N$. benthamiana. The results indicate that all effectors were localized in the nucleus and cytoplasm (Figure 3). Western blotting results showed that they were normally expressed and accumulated in leaves cells (Figure 4). 


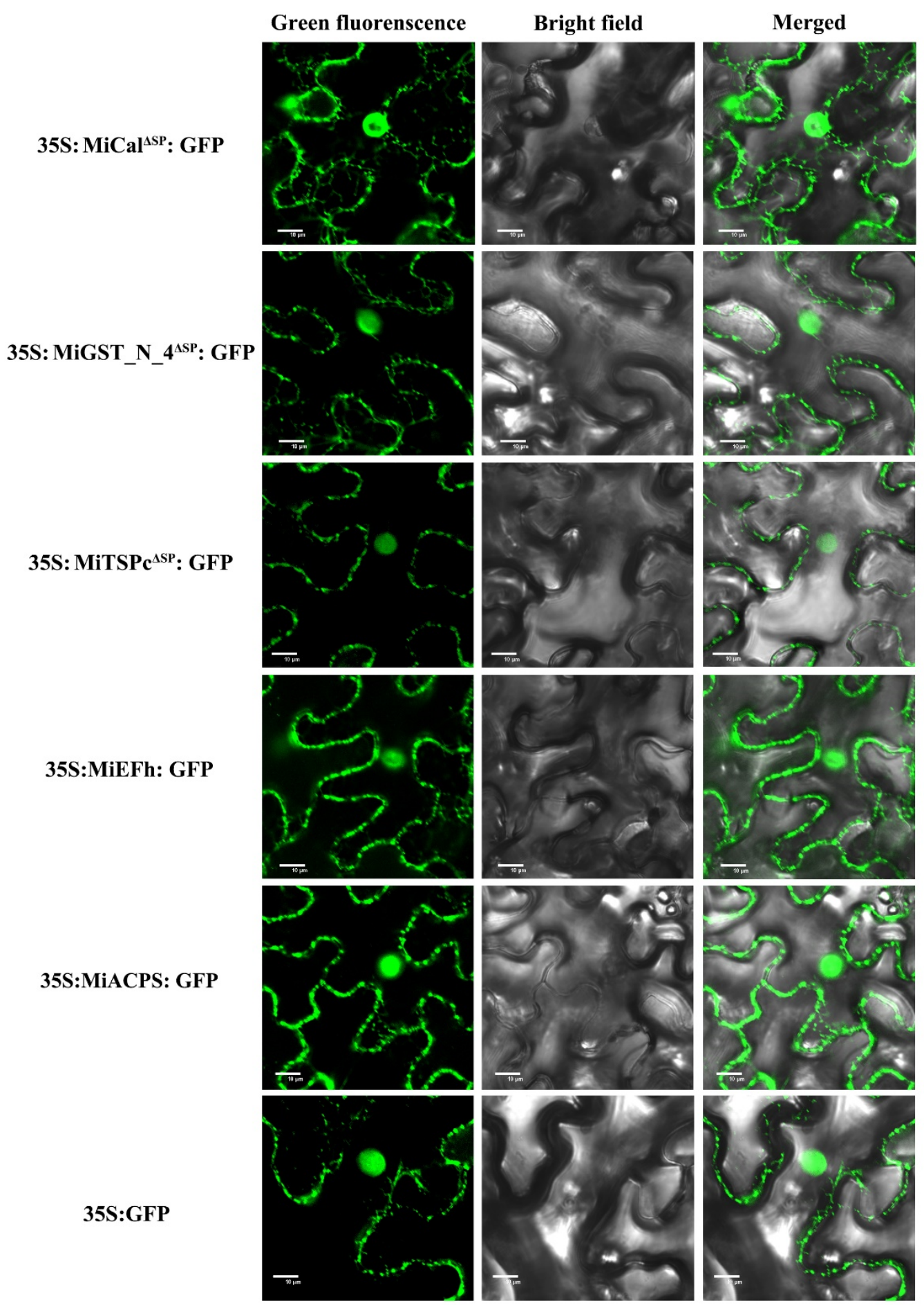

Figure 3. Subcellular localization of the five effectors when expressed in plant cells. Agrobacterium culture harboring the 35S: $\mathrm{MiCal}^{\Delta S P}:$ GFP, 35S: MiGST_N_4 ${ }^{\Delta S P}$ : GFP, 35S: MiTSPc ${ }^{\triangle S P}$ : GFP, 35S: MiEFh: GFP, and 35S: MiACPS: GFP construct were hand-injected into WT Nicotiana benthamiana leaves at an inoculum of $\mathrm{OD}_{600}=1$. Epidermal leaf tissues were collected and subjected to microscopy with a confocal laser scanning microscope post infiltration $48 \mathrm{~h}$. The experiment was conducted three times with similar results. Scale bars, $10 \mu \mathrm{m}$. 


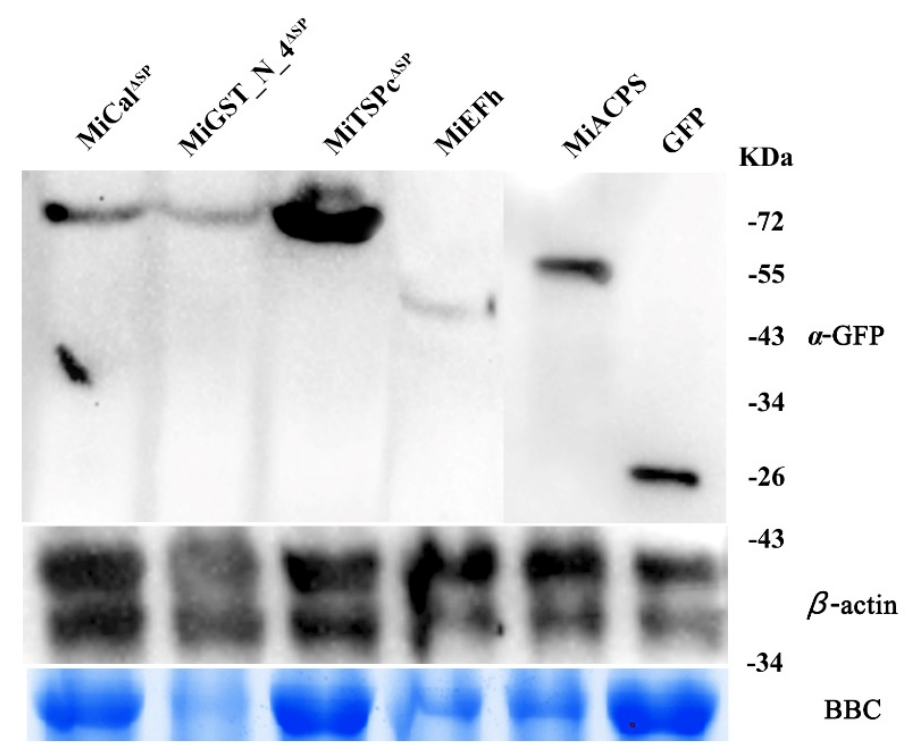

Figure 4. The normal expression and accumulation of all effectors in plant cells were analyzed by Western blotting. Protein detection used anti-GFP to detect the expression of effectors. The use of Coomassie brilliant blue (CBB) staining showed the loaded protein samples.

\subsection{Expression Pattern Analysis of Five Effectors in M. incognita}

The newly hatched pre-J2 of $M$. incognita were inoculated with RKN-susceptible tobacco variety W38, and the nematodes were extracted at different developmental stages (Figure 5A). The expression of each effector gene at different developmental stages was analyzed by RT-qPCR. The results showed that the effector MiGST_N_4 was barely expressed before inoculation and was strongly expressed immediately after inoculation. After that, its expression significantly increased at the parasitic third-stage juveniles (J3)/parasitic fourthstage juveniles (J4) stage, but decreased at female stage. MiCal and MiEFh genes showed similar expression trends, with weak expression before inoculation, and were increased at the parasitic second-stage juveniles (Pra-J2) stage after inoculation, and continued at the $\mathrm{J} 3 / \mathrm{J} 4$ stage, peaking at the $\mathrm{J} 3 / \mathrm{J} 4$ stage, after which their expression began to decline at the female stage, but was still higher than at the pre-parasitic second-stage juveniles (pre-J2) stage before inoculation. The expression of the MiACPS effector gene was almost absent in the pre-J2 stage before inoculation, was up-regulated after inoculation and reached a peak point in the J3/J4 stage, then decreased significantly in the female stage, but the expression was almost the similar as that in the Pra-J2 stage. The effector MiTSPc was barely expressed at the pre-J2 stage before inoculation, its expression started to increase after inoculation and continued to the female development stage (Figure 5).

\subsection{Effectors Can't Induce Defense-Related Cell Death in the RKN-Susceptible Tobacco Variety W38}

Leaf transient expression was used to study the effector functions in plant-nematode interactions. In particular, it was used to investigate their roles in the elicitation of defense signaling [53]. Since the expression of different effectors at different development stages was not the same, we analyzed whether these effectors could induce defense responses or not. The results showed that after 5 days of transient expression of effectors in the RKNsusceptible tobacco variety W38, trace amounts of ROS remained in the leaf expression region for five effectors, and only faint traces of ROS could be observed, with the MiCal effector no traces of ROS were observed (Figure 6A,B). None of the five effectors induced $\mathrm{HR}$ in the RKN-susceptible tobacco variety W38 and only traces of pinholes could be observed (Figure 6C,D). Ion leakage analysis of the injected area showed that all effectors have similar effects as the control (Figure 6E). Western blotting data showed that all five effector fusion proteins were expressed in the RKN-susceptible tobacco variety W38 leaves (Figure 6F). 
(A)

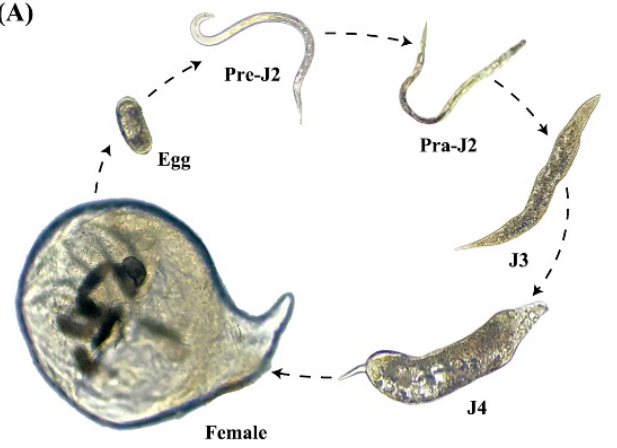

(C)

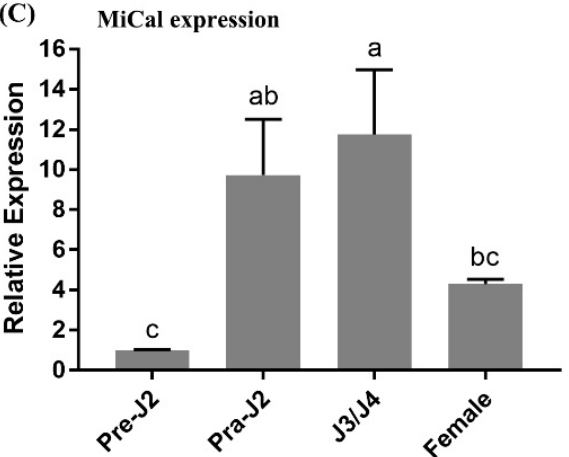

(E)

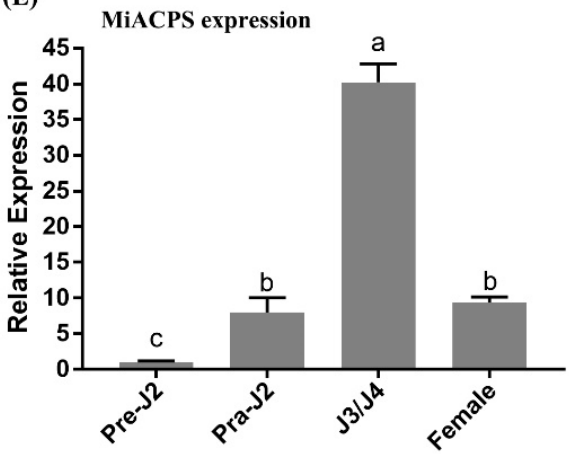

(B)

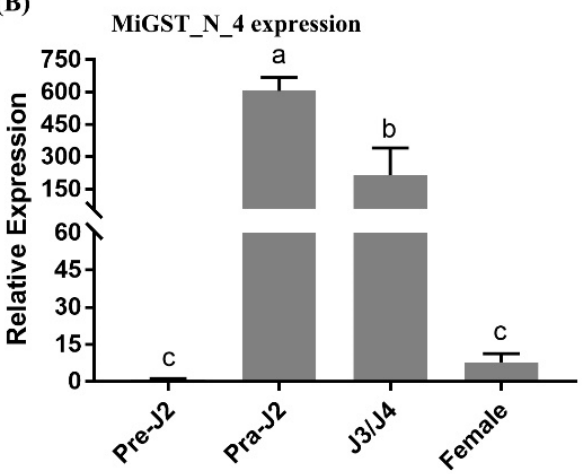

(D)

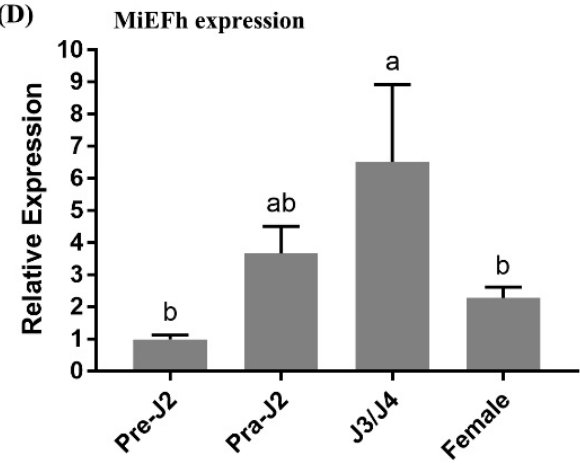

(F)

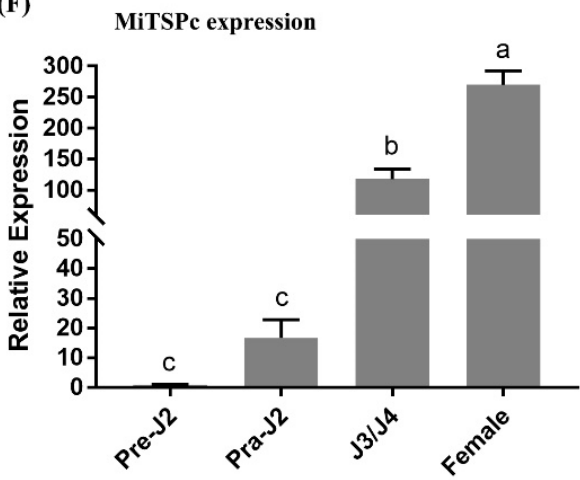

Figure 5. Developmental expression of the five effectors of M. incognita. (A) The growth cycle of M. incognita. "Egg" indicates eggs obtained from gall masses; "Pre-J2" indicates newly hatched pre-parasitic second-stage juveniles M. incognita from eggs; "Pra-J2" indicates parasitic secondstage juveniles collected from the RKN-susceptible tobacco variety W38 after inoculated with Pre-J2 M. incognita for 7 days; "J3/J4" indicates parasitic third-stage juveniles (J3)/ parasitic fourth-stage juveniles (J4) collected from the RKN-susceptible tobacco variety W38 after inoculated with Pre-J2 M. incognita 14 days to 21 days. Female indicates female $M$. incognita isolated from tobacco roots after 30 days of inoculation with Pre-J2 M. incognita. (B-F) Life stage expression of the five effectors. The relative expression levels of MiGST_N_4, MiCal, MiEFh, MiACPS, and MiTSPc were quantified using quantitative RT-qPCR of four different $M$. incognita life stages: pre-J2, pra-J2, J3/J4, and female. The actin gene was used as a reference gene. The values were calculated using the $2^{-\triangle \triangle C t}$ method and presented as the fold-change in mRNA level in various nematode developmental stages relative to that of pre-J2. Means $\pm \mathrm{SD}$ were shown. The results shown are representative of at least three independent experiments. Different letters indicate significant differences based on one-way analysis of variance (ANOVA) followed by Duncan's multiple range test $(p<0.05)$. 

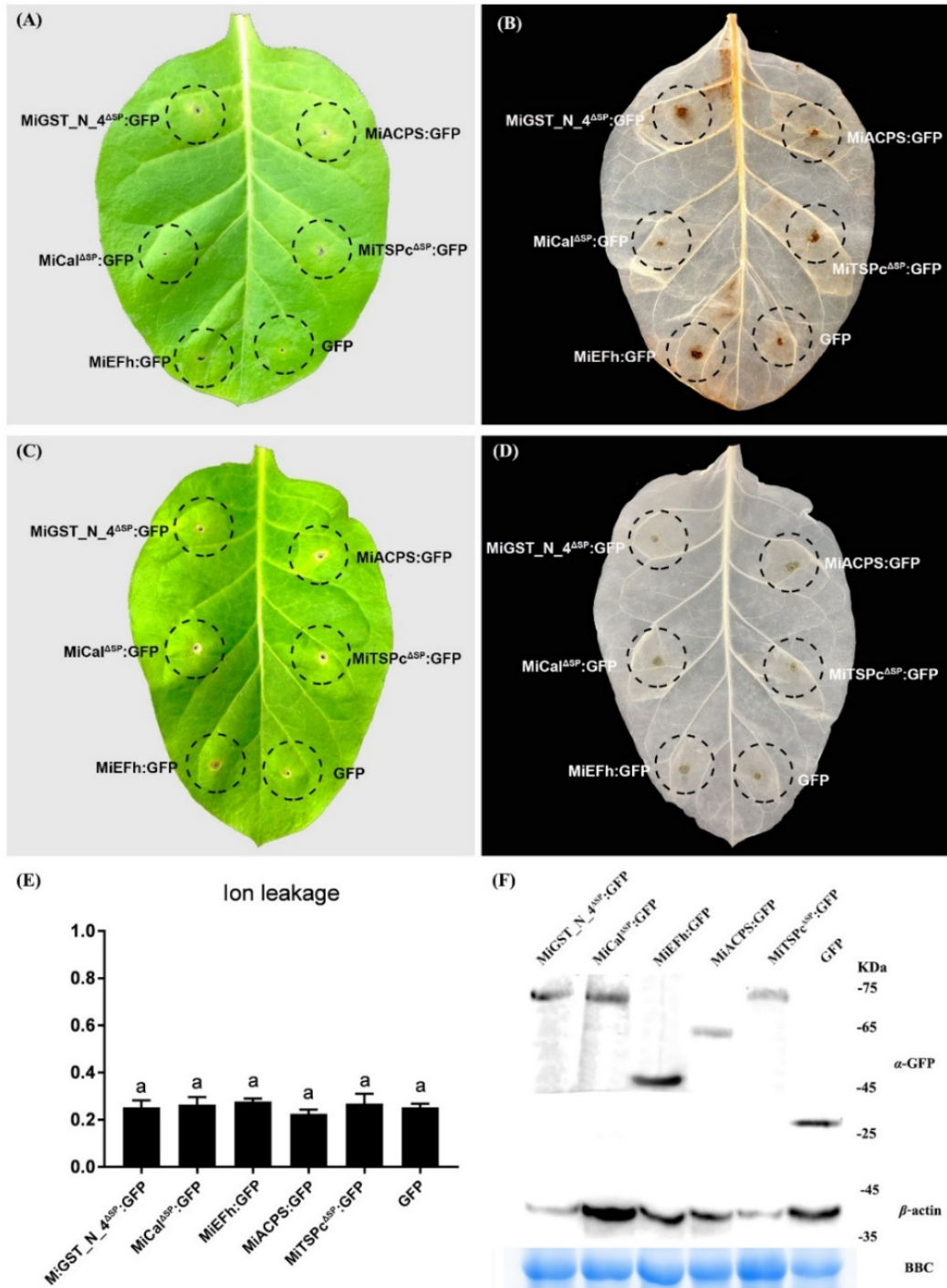

Figure 6. Analysis of reactive oxygen species (ROS) and hypersensitive response (HR) after inoculation of five effectors in the leaves of RKN-susceptible tobacco variety W38. The experiment was repeated at least three times, and each assay consisted of at least five plants with three leaves inoculated similarly. (A,C) The left panel shows a representative leaf of A. tumefaciens GV3101 carrying the vectors of MiGST_N_4 ${ }^{\Delta S P}$ : GFP, MiCal ${ }^{\Delta S P}$ : GFP, MiEFh: GFP, MiACPS: GFP and MiTSPc ${ }^{\Delta S P}:$ GFP constructs injected into the leaves RKN-susceptible tobacco variety W38. Five representative leaves were photographed after 5 days. $\mathrm{OD}_{600}=1$. (B) shows leave cleared with $3,3^{\prime}$-diaminobenzidine blue (DAB). The brown area represents $\mathrm{H}_{2} \mathrm{O}_{2}$ localization. (D) Leaves cleared by ethanol injected with effectors after 5 days. (E) Ion leakage (mean $\pm \mathrm{SE}, n>5$ ) was measured after injecting the effector $72 \mathrm{~h}$. Error bars represent $\pm \mathrm{SD}$ of three independent experiments. Letters on the bars indicate variability between samples $(p<0.05)$. Different letters indicate significant differences based on one-way analysis of variance (ANOVA) followed by Duncan's multiple range test. (F) Normal expression and accumulation of all tested proteins in leaves as indicated by Western blotting analysis. Coomassie brilliant blue (CBB) staining was used to show equal up-sampling of protein samples.

\subsection{Effectors Trigger Defense-Related Cell Death in the RKN-Resistance Tobacco Variety K326}

Since the five effectors caused weak ROS accumulation in the RKN-susceptible tobacco variety W38 but could not induce HR, we tested whether those effectors could trigger ROS and HR in the RKN-resistance tobacco variety K326. The results showed that MiGST_N_4, MiEFh, MiACPS, and MiTSPc caused cell necrosis, and strong ROS could be observed at the injection sites (Figure 7A,B). The results of HR were similar to those of ROS; for 
instance, MiGST_N_4, MiEFh, MiACPS, and MiTSPc caused significant HR, while MiCal did not cause any HR (Figure 7C,D). Ion leakage assay of the injected region showed that the ion permeation rates of MiGST_N_4, MiEFh, MiACPS, and MiTSPc were significantly higher than the control, while the ion permeation rates of MiCal effectors were not different from the control (Figure 7E). Western blotting data showed that all effector fusion proteins accumulated in the RKN-resistance tobacco variety K326 leaves (Figure 7F). These results indicate that MiGST_N_4, MiEFh, MiACPS and MiTSPc can elicit the ROS burst, strong $\mathrm{HR}$ and significant ion leakage levels in resistant tobacco plants.
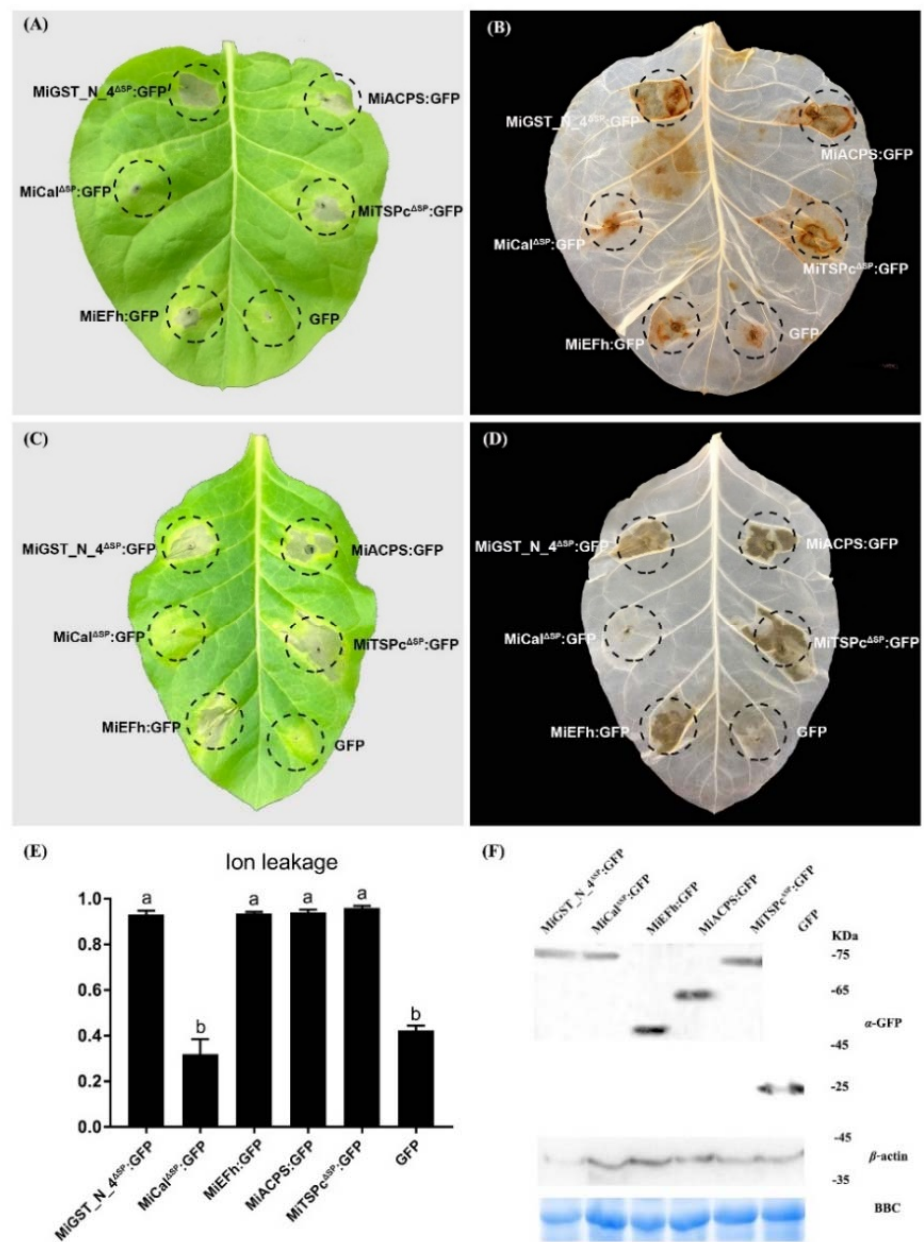

Figure 7. Analysis of ROS and HR after inoculation of five effectors in the RKN-resistance tobacco variety K326. The experiment was repeated at least three times, and each assay consisted of at least five plants with three leaves inoculated similarly. (A,C) shows a representative leaf of $A$. tumefaciens GV3101 harboring the vectors of MiGST_N_4 ${ }^{\Delta S P}$ : GFP, MiCal ${ }^{\Delta S P}:$ GFP, MiEFh: GFP, MiACPS: GFP, and MiTSPc ${ }^{\triangle S P}$ : GFP constructs injected into the RKN-resistance tobacco variety K326. The HR occurred in the leaf at the injection position of 5 days after inoculation with the effector. Five representative leaves were photographed after 5 days. $\mathrm{OD}_{600}=1$. (B) Leaves cleared with 3,3'diaminobenzidine blue (DAB). The brown area represents $\mathrm{H}_{2} \mathrm{O}_{2}$ localization. (D) leaves cleared by ethanol injected with effectors after 5 days. (E) Ion leakage (mean $\pm \mathrm{SE}, n>5$ ) was measured $72 \mathrm{~h}$ after effector injection in the RKN-resistance tobacco variety K326. Error bars represent \pm SD of three independent experiments. Letters $\mathrm{a}-\mathrm{b}$ on the bars indicate significant differences $(p<0.05)$ between samples. Different letters indicate significant differences based on one-way analysis of variance (ANOVA) followed by Duncan's multiple range test. (F) Normal expression and accumulation of all tested proteins in plant cells as indicated by Western blotting analysis. Coomassie brilliant blue (CBB) staining was used to show equal up-sampling of protein samples. 


\section{Discussion}

Root-knot nematodes spend most of their life cycle inside the host root and feed on living tissue. To promote parasitism, a variety of effectors are secreted to degrade plant cell walls, absorb nutrients, manipulate defense systems, and establish feeding sites [54,55]. The genome of $M$. incognita analysis revealed that there are about 10,000 proteins; the function of most of these proteins is unknown [56]. Current studies mainly focused on the species with signal peptides at the N-terminal. However, only about $10 \%$ of the proteins in $M$. incognita contain signal peptides, and most effectors do not contain any signal peptides [57]. Few studies have been conducted on these effectors that do not contain signal peptides. In this study, we obtained five $M$. incognita effector proteins that may interact with PsoRPM3 protein by IP and LC-MS in P. sogdiana. The five effectors were named MiCal, MiGST_N_4, MiTSPc, MiEFh, and MiACPS, and their molecular weights and structures differed significantly. MiCal, MiGST_N_4, and MiTSPc effectors have signal peptides at the N-terminus, while MiEFh and MiACPS effectors do not have signal peptides, indicating that the effectors associated with PsoRPM3 are also diverse.

Root-knot nematodes secrete effectors mainly through the three specialized secretory oesophageal glands, one DG, and two SvG [54,58]. Generally, the SvG play a major role during the nematode invasion and migration stages. The cells of the SvG are more active before nematode invasion but begin to atrophy and become smaller during the later stages of parasitism after nematode fixation. In contrast, the DG begins to grow longer after parasitization and plays a major role in the formation and maintenance of feeding sites [59]. During the migration process, nematodes secrete effectors from apoplasts to plant tissues via stylets $[60,61]$. Therefore, precise positioning of effectors can provide a better understanding of their biological functions. In this study, we showed that MiCal, MiGST_N_4, MiEFh, and MiACPS effectors were secreted in the SvG of pre-J2 M. incognita, whereas MiTSPc effectors were secreted in the DG, suggesting that they play different roles during parasitism. Expression analysis of five effectors at different developmental stages of nematodes showed that MiGST_N_4, MiCal, MiEFh and MiACPS effectors secreted in the SvG had higher expression levels at the pra-J2 stage and J3/J4 stage, but significantly lower expression at the female stage, indicating that these four effectors secreted in the SvG are necessary in the early stage of parasitism. The effector MiTSPc is secreted by the DG, and its expression was highest in the female stage, suggesting that effectors MiTSPc may play a role in the formation and maintenance of feeding sites in the late parasitic stage.

Root-knot nematode effectors entering host tissues can promote parasitism and change plant functions by binding to their proteins [60,62]. For instance, the MiMIF-2 effector of M. incognita disrupts plant cell metabolism and the SA-mediated immune response through enzymatic activity [63]. MiISE5 regulates multiple signaling pathways in the early stage of parasitism and suppresses the host's resistance response [25]. In addition, the Mi-CRT, MjTTL5, and MiMsp40 effectors of M. incognita have shown similar functions [27,39,64]. Inhibition of plant immune responses by these effectors generally requires targeting the host cell nucleus and disrupting plant immunity via alteration of the plant cell cycle through the manipulation of processes $[65,66]$. The $7 \mathrm{H} 08$ effector of $M$. incognita has transcriptional activity in plants, but the target gene in the host has not been determined yet [67]. The 16D10 effector gene of M. incognita targets Scarecrow-like transcription factors [68]. Thus, effectors with nuclear localization signals are thought to play a critical role in the regulation of plant immune responses. This study found five effectors, located in the membrane and nucleus of plant cells having different intensity of fluorescence signals. The fluorescence signals of MiCal, MiEFh and MiACPS were stronger in the cell membrane and nucleus; MiGST_N_4 had a stronger signal in the nucleus than in the cell membrane, and MiTSPc had a weaker signal in both the nucleus and the cell membrane, suggesting that these five effectors may have different roles in the parasitic process. There was almost no ROS production in the RKN-susceptible tobacco variety W38, and no HR at all. In contrast, four effectors (MiGST_N_4, MiEFh, MiACPS, and MiTSPc) in the RKN-resistance tobacco 
variety K326 elicited HR and produced a strong ROS accumulation, indicating that these four effectors may be involved in triggering the immune response of the host plant.

\section{Materials and Methods}

\subsection{Plant Materials and Nematodes}

Seeds were sown using the RKN-susceptible tobacco variety W38 and the RKNresistance tobacco variety K326 carrying the gene $R k 1$ resistant to $M$. incognita [69]. The plants grown at $28{ }^{\circ} \mathrm{C}$ under a $16 \mathrm{~h}$ light $/ 8 \mathrm{~h}$ dark cycle. One-month seedlings were inoculated with $M$. incognita infective juveniles. $N$. benthamiana was used for subcellular localization experiments 3 weeks after sowing.

We followed the method reported by Huang et al. [70] to collect the M. incognita at different developmental stages. Briefly, we rinsed the RKN-susceptible tobacco variety W38 tobacco roots that had been inoculated with $M$. incognita after 7, 14, 21, and 30 days with tap water, cut them into $\sim 1 \mathrm{~cm}$ sticks, immersed roots in the Pectinex and Celluclast mix, incubated the mixture for $4 \mathrm{~h}$ (overnight) at RT under gentle agitation (orbital shaker, 50 rounds per minute), and purified the nematodes by sucrose gradient centrifugation. According to the report on the life history of M. incognita by Abad et al. [57], the Par-J2, J3/J4 and females were collected with a pipette under a stereo microscope. In addition, newly hatched pre-J2 of M. incognita were used for in situ hybridization and RNA extraction for gene cloning.

\subsection{PsoRPM3 Protein Immunoprecipitation (IP) Experiments and LC-MS Analysis}

PsoRPM3 protein IP experiments and LC-MS analysis was conducted according to the method reported by Xiao et al. [71]. Briefly, the PsoRPM3 carrying the MBP tag protein was constructed into the prokaryotic expression vector $\mathrm{pMal}-\mathrm{c} 2 \mathrm{x}$, and the fusion protein MBP-PsoRPM3 was induced to express overnight at $37^{\circ} \mathrm{C}$ and $180 \mathrm{rpm}$. After sonication, the supernatant was collected and the fusion protein was collected using MBP beads (New England Biolabs, Ipswich, MA, USA). The total protein derived from the root inoculated with 10,000 pre-J2 of M. incognita after 3 days, and the total protein of roots that had not been inoculated with $M$. incognita were used as controls. Incubate in a shaker at $4{ }^{\circ} \mathrm{C}$ for $2 \mathrm{~h}$. After centrifugation and elution, the protein was sent to Beijing Qinglian Biotech Co., Ltd. for the LC/MS tests. The acquired mass spectrometric data were analyzed using ProteomeDiscoverer2.1 and then anatomized for searches of the NCBI (https: / / www.ncbi.nlm.nih.gov, accessed on 12 September 2019) database and M. incognita (https: / / www6.inrae.fr/meloidogyne_incognita/, accessed on 15 September 2019) database.

\subsection{Gene Amplification and Sequence Analysis}

Total RNA was extracted from $M$. incognita different developmental stages collected, as described above, by Trizol (Invitrogen, Waltham, MA, USA). First-strand cDNA was synthesized using the Novo Script Plus All-in-one 1st strand cDNA synthesis SuperMix (Novoprotein Scientific Inc, Shanghai, China). To clone the effector gene sequence, primers covering the whole sequence were designed to perform PCR from CDNA templates. For PCR amplification, $200 \mathrm{ng}$ of cDNA template was used in a $50 \mu \mathrm{L}$ reaction mixture consisting of $2 \times$ PCR buffer for KOD FX, 2 mM dNTPs, 10 pM for each primer, and $1.0 \mathrm{U}$ KOD FX (TOYOBO Co., Ltd., Kita-ku, Osaka, Japan). All primers were synthesized by Sangon Biotech Co., Ltd. (Shanghai, China) and are listed in Supplementary Table S1.

To analysis protein sequences of the effectors, SignalP 5.0 (www.cbs.dtu.dk/services / SignalP/, accessed on 20 November 2019), SMART (http:/ / smart.embl-heidelberg.de/, accessed on 22 November 2019), ExPASy (https:/ / web.expasy.org/protparam/, accessed on 20 November 2019) and Motif Scan (https://myhits.sib.swiss/cgi-bin/motif_scan, accessed on 25 November 2019) were used to predict potential traits of effector proteins. 


\subsection{In Situ Hybridization of Effectors in Pre-J2}

In situ hybridization was performed using digoxigenin-labeled cDNA probes on freshly hatched pre-J2 of $M$. incognita to detect the expression and secretion sites of effectors [72]. Targeted effector fragments were amplified using specific primers (Supplementary Table S1). PCR products were used as templates for asymmetric PCR using the MyLab ${ }^{\mathrm{TM}}$ Digoxin Labeling and Hybridization Detection Kit (Beijing Merab Medical Technology Co., Ltd., Beijing, China) to synthesize DIG-labeled sense and antisense cDNA probes. A total of 10,000 newly hatched pre-J2 of M. incognita were collected, fixed, transparent, and hybridized according to the method reported by Jaouannet et al. [73]. Hybridization probes were immunodetected with anti-DIG-AP enzyme complexes followed by NBT/BCIP chromogenic substrates. The hybridized nematodes were observed and photographed with an Axio Imager M2 microscope.

\subsection{Developmental Expression Analysis}

RNA samples were extracted from pre-J2, pra-J2, J3/J4 and Female stages isolated from the RKN-susceptible tobacco variety W38 as described above. The cDNA was synthesized using TransScript All-in-One First-Strand cDNA Synthesis SuperMix (Transgen Biotech, Beijing, China). RT-qPCR was conducted in an ABI Prism 7000 real-time PCR system (Applied Biosystems, Forster City, CA, USA). Root-knot nematode actin protein was used as an internal reference. PCR was performed using the SuperReal PreMix Plus (Tiangen Biotech Co., Ltd., Beijing, China) kit with a PCR program of $30 \mathrm{~s}$ at $95{ }^{\circ} \mathrm{C}$ for 40 cycles, followed by $5 \mathrm{~s}$ at $95^{\circ} \mathrm{C}, 31 \mathrm{~s}$ at $60^{\circ} \mathrm{C}$, and $15 \mathrm{~s}$ at $95^{\circ} \mathrm{C}$. The results were analyzed using the $2^{-\Delta \Delta C t}$ method [74] for data analysis. Three technical replicates and independent experiments replicates were performed for each reaction in all experiments.

\subsection{Subcellular Localization}

A. tumefaciens strains of GV3101 harboring the construct of 35S: $\mathrm{MiCal}^{\triangle \mathrm{SP}}$ : GFP, 35S: MiGST_N_4 $4^{\Delta S P}:$ GFP, 35S: MiTSPc ${ }^{\Delta S P}:$ GFP, 35S: MiEFh: GFP, 35S: MiACPS: GFP were suspended in infiltration buffer to an $\mathrm{OD}_{600}$ of 1 and were syringe-infiltrated to into the leaves of three- to four-week-old N. benthamiana plants as described by Zhao et al. [31]. The strain GV3101 carrying 35S: GFP was used as a control. Leaf tissue collected $48 \mathrm{~h}$ after infiltration was visualized under a confocal laser-scanning microscope (Zeiss LSM 880) at an excitation wavelength of $488 \mathrm{~nm}$ and emission was detected at 495-530 nm [75].

\subsection{Effector Virulence Testing}

To test whether the effectors could trigger cell death, an assay for triggered cell death was performed in tobacco (the RKN-susceptible tobacco variety W38 and the RKNresistance tobacco variety K326). The cultured A. tumefaciens strains of GV3101 carrying the construct of effectors as above $\left(\mathrm{OD}_{600}=1\right)$ were initially infiltrated into the tobacco leaves. Simultaneously, the GFP gene was expressed alone as a control. The leaves were monitored for symptoms, and photographs were acquired 5 days after infiltration. The experiment was repeated at least three times, and each assay consisted of at least five plants with three leaves inoculated similarly.

\section{8. $\mathrm{H}_{2} \mathrm{O}_{2}$ Detection}

$\mathrm{H}_{2} \mathrm{O}_{2}$ was detected according to previous studies [76,77]. Briefly, incubated tobacco leaves were placed in 3,3'-diaminobenzidine (DAB)-HCI (Beijing Nobled Technology Co., Ltd., Beijing, China) (1 mg/mL $\left.\mathrm{mL}^{-1}, \mathrm{pH} 3.8\right)$ solution and incubated for $8 \mathrm{~h}$. Leaves were cleared in boiling $96 \%$ ethanol for $10 \mathrm{~min}$ and stored in $96 \%$ ethanol for visualizing.

\subsection{Electrolyte Leakage Detection}

Ion leakage was measured as described previously [78]. Briefly, five-leaf discs $(1.2 \mathrm{~cm}$ diameter) were harvested from tobacco leaves post-agroinfiltration and put in $5 \mathrm{~mL}$ of sterile $\mathrm{H}_{2} \mathrm{O}_{2}$ in a 15-mL polypropylene tube. The samples were shaken at room temperature 
for $3 \mathrm{~h}$, and conductivity (C1) was measured by a conductivity meter (Model 4403, Markson Science, Inc., Del Mar, CA, USA). Samples were then boiled for $15 \mathrm{~min}$, and the conductivity was measured again as the $C 2$ value. Ion leakage was calculated as $C 1 / C 2$ ratio. All assays were repeated three times. Statistical analyses were performed using GraphPad Prism 7.0 (GraphPad Software, San Diego, CA, USA).

\subsection{Protein Extraction and Western Blot Analysis}

A. tumefaciens GV3101 strain expressing GFP-epitope tagged proteins was infiltrated into tobacco (the RKN-susceptible tobacco variety W38 and the RKN-resistance tobacco variety K326) for expression. Leaf tissue was collected $36 \mathrm{~h}$ after infiltration and stored at $-80{ }^{\circ} \mathrm{C}$ until further use. Tobacco leaf tissue was ground with liquid nitrogen and with lysis buffer $(10 \mu \mathrm{L} 100$ mM PMSF, $1 \mu \mathrm{L}$ Cocktail, $14 \mu \mathrm{L} \mathrm{10 \%}$ Tralatone, and $1 \mathrm{~mL}$ protein extraction buffer; Huaxing Boltons, Beijing, China), and centrifuged at $12,000 \times g$ for $25 \mathrm{~min}$. Proteins were separated by SDS-PAGE in an $8 \%$ gel. Western blotting was carried out using the semidry method on polyvinylidene difluoride (PVDF) membranes. Blots were probed with mouse anti-GFP antibodies (Pao Yijie Technology Co., Beijing, China) at a dilution of 1:5000. The secondary goat-anti-mouse antibody (HRP) was used at a dilution of 1: 5000. The signal was visualized with the eECL Western Blot Kits (Kangwei Century Biotechnology Co., Ltd., Beijing, China) according to the manufacturer's instruction.

Supplementary Materials: The following supporting information can be downloaded at: https: / / www.mdpi.com/article/10.3390/ijms23031498/s1.

Author Contributions: Conceptualization, J.H.; PsoRPM3 protein immunoprecipitation (IP) experiments, K.X.; methodology, J.H., W.P. and H.Z.; validation, W.P.; analysis, W.P., H.Z., S.L., C.G. and Z.Y.; writing —original draft preparation, W.P. and J.H.; writing—review and editing, J.H. and W.P.; project administration, J.H. All authors have read and agreed to the published version of the manuscript.

Funding: This work is supported by the National Natural Science Foundation of China (31972360).

Institutional Review Board Statement: Not applicable.

Informed Consent Statement: Not applicable.

Acknowledgments: We thank Heng Jian from China Agricultural University for providing the root-knot nematode (Meloidogyne incognita).

Conflicts of Interest: The authors declare no conflict of interest.

\section{References}

1. Nicol, J.M.; Turner, S.J.; Coyne, D.L.; Nijs, L.D.; Hockland, S.; Maafi, Z.T. Current Nematode Threats to World Agriculture. In Genomics and Molecular Genetics of Plant-Nematode Interactions; Jones, J., Gheysen, G., Fenoll, C., Eds.; Springer: Dordrecht, The Netherlands, 2011; pp. 21-43.

2. Moens, M.; Perry, R.N.; Starr, J.L. Meloidogyne species-A diverse group of novel and important plant parasites. In Root-Knot Nematodes; CABI: Wallingford, UK, 2009; pp. 1-17.

3. Jones, J.T.; Haegeman, A.; Danchin, E.G.J.; Gaur, H.S.; Helder, J.; Jones, M.G.K.; Kikuchi, T.; Manzanilla-López, R.; Palomares-Rius, J.E.; Wesemael, W.M.L.; et al. Top 10 plant-parasitic nematodes in molecular plant pathology. Mol. Plant Pathol. 2013, 14, 946-961. [CrossRef] [PubMed]

4. Forghani, F.; Hajihassani, A. Recent Advances in the Development of Environmentally Benign Treatments to Control Root-Knot Nematodes. Front. Plant Sci. 2020, 11, 1125. [CrossRef] [PubMed]

5. Khan, M. Nematode infestation, a potential threat to Indian forests. Indian Phytopathol. 2020, 73, 397-414. [CrossRef]

6. Abad, P.; Favery, B.; Rosso, M.-N.; Castagnone-Sereno, P. Root-knot nematode parasitism and host response: Molecular basis of a sophisticated interaction. Mol. Plant Pathol. 2003, 4, 217-224. [CrossRef]

7. Haegeman, A.; Jones, J.T.; Danchin, E.G.J. Horizontal Gene Transfer in Nematodes: A Catalyst for Plant Parasitism? Mol. Plant-Microbe Interact. 2011, 24, 879-887. [CrossRef] [PubMed]

8. Chen, W.; Qiao, F.; Ma, K.; Wang, J.; Hu, J. Roles of CCS52A gene and endoreduplication during the formation of giant cells in Xinjiang wild myrobalan. J. China Agric. Univ. 2018, 23, 43-52.

9. Chen, X.; Xiao, K.; Zhu, X.; Chen, W.; Yang, Y.; Hu, J. Development of Giant Cells and Roles of CCS52B Gene Work in Meloidogyne incognita Resistant Prunus sogdiana. Acta Hortic. Sin. 2015, 42, 843-852. 
10. Jones, J.T.; Kumar, A.; Pylypenko, L.A.; Thirugnanasambandam, A.; Castelli, L.; Chapman, S.; Cock, P.J.A.; Grenier, E.; Lilley, C.J.; Phillips, M.S.; et al. Identification and functional characterization of effectors in expressed sequence tags from various life cycle stages of the potato cyst nematode Globodera pallida. Mol. Plant Pathol. 2009, 10, 815-828. [CrossRef]

11. Bellafiore, S.; Shen, Z.; Rosso, M.-N.; Abad, P.; Shih, P.; Briggs, S. Direct Identification of the Meloidogyne incognita Secretome Reveals Proteins with Host Cell Reprogramming Potential. PLoS Pathog. 2008, 4, e1000192. [CrossRef]

12. Kumar, S.; Koutsovoulos, G.; Kaur, G.; Blaxter, M. Toward 959 nematode genomes. Worm 2012, 1, 42-50. [CrossRef] [PubMed]

13. Petitot, A.-S.; Alexis, D.; Mawusse, A.; Corinne, D.; Julie, G.; Morgane, A.; Fernandez, D. Dual RNA-seq reveals Meloidogyne graminicola transcriptome and candidate effectors during the interaction with rice plants. Mol. Plant Pathol. 2015, 17, 860-874. [CrossRef] [PubMed]

14. Gahoi, S.; Gautam, B. Genome-wide analysis of Excretory/Secretory proteins in root-knot nematode, Meloidogyne incognita provides potential targets for parasite control. Comput. Biol. Chem. 2017, 67, 225-233. [CrossRef] [PubMed]

15. Kumara Tn, S.; Papolu, P.; Dutta, T.; Kamaraju, D.; Chaudhary, S.; Rao, U. RNAi-induced silencing of an effector confers transcriptional oscillation in another group of effectors in the root-knot nematode, Meloidogyne incognita. Nematology 2016, 18, 857-870.

16. Siddique, S.; Grundler, F.M.W. Parasitic nematodes manipulate plant development to establish feeding sites. Curr. Opin. Microbiol. 2018, 46, 102-108. [CrossRef] [PubMed]

17. Kyndt, T.; Vieira, P.; Gheysen, G.; de Almeida-Engler, J. Nematode feeding sites: Unique organs in plant roots. Planta 2013, 238, 807-818. [CrossRef]

18. Gillet, F.-X.; Bournaud, C.; Antonino, J.; Grossi-de-Sá, M. Plant-parasitic nematodes: Towards understanding molecular players in stress responses. Ann. Bot. 2017, 119, 775-789. [CrossRef]

19. Castagnone-Sereno, P.; Deleury, E.; Danchin, E.G.J.; Perfus-Barbeoch, L.; Abad, P. Data-mining of the Meloidogyne incognita degradome and comparative analysis of proteases in nematodes. Genomics 2011, 97, 29-36. [CrossRef]

20. Favery, B.; Quentin, M.; Jaubert-Possamai, S.; Abad, P. Gall-forming root-knot nematodes hijack key plant cellular functions to induce multinucleate and hypertrophied feeding cells. J. Insect Physiol. 2015, 84, 60-69. [CrossRef]

21. Ali, M.A.; Azeem, F.; Li, H.; Bohlmann, H. Smart Parasitic Nematodes Use Multifaceted Strategies to Parasitize Plants. Front. Plant Sci. 2017, 8, 1699. [CrossRef]

22. Eves-van den Akker, S.; Laetsch, D.R.; Thorpe, P.; Lilley, C.J.; Danchin, E.G.J.; Da Rocha, M.; Rancurel, C.; Holroyd, N.E.; Cotton, J.A.; Szitenberg, A.; et al. The genome of the yellow potato cyst nematode, Globodera rostochiensis, reveals insights into the basis of parasitism and virulence. Genome Biol. 2016, 17, 124. [CrossRef]

23. Mejias, J.; Truong, N.M.; Abad, P.; Favery, B.; Quentin, M. Plant Proteins and Processes Targeted by Parasitic Nematode Effectors. Front. Plant Sci. 2019, 10, 970. [CrossRef] [PubMed]

24. Da Rocha, M.; Bournaud, C.; Dazenière, J.; Thorpe, P.; Bailly-Bechet, M.; Pellegrin, C.; Péré, A.; Grynberg, P.; Perfus-Barbeoch, L.; Eves-van den Akker, S.; et al. Genome Expression Dynamics Reveal the Parasitism Regulatory Landscape of the Root-Knot Nematode Meloidogyne incognita and a Promoter Motif Associated with Effector Genes. Genes 2021, 12,771. [CrossRef] [PubMed]

25. Shi, Q.; Mao, Z.; Zhang, X.; Zhang, X.; Wang, Y.; Ling, J.; Lin, R.; Li, D.; Kang, X.; Sun, W.; et al. A Meloidogyne incognita effector MiISE5 suppresses programmed cell death to promote parasitism in host plant. Sci. Rep. 2018, 8, 7256. [CrossRef]

26. Xie, J.; Li, S.; Mo, C.; Wang, G.; Xiao, X.; Xiao, Y. A Novel Meloidogyne incognita Effector Misp12 Suppresses Plant Defense Response at Latter Stages of Nematode Parasitism. Front. Plant Sci. 2016, 7, 964. [CrossRef] [PubMed]

27. Niu, J.; Liu, P.; Liu, Q.; Chen, C.; Guo, Q.; Yin, J.; Yang, G.; Jian, H. Msp40 effector of root-knot nematode manipulates plant immunity to facilitate parasitism. Sci. Rep. 2016, 6, 19443. [CrossRef]

28. Dubreuil, G.; Magliano, M.; Deleury, E.; Abad, P.; Rosso, M.N. Transcriptome analysis of root-knot nematode functions induced in the early stages of parasitism. New Phytol. 2007, 176, 426-436. [CrossRef]

29. Mejias, J.; Bazin, J.; Truong, N.M.; Chen, Y.; Marteu, N.; Bouteiller, N.; Sawa, S.; Crespi, M.; Vaucheret, H.; Abad, P.; et al. Root-knot nematode effector MiEFF18 interacts with the plant core spliceosomal protein SmD1 required for giant cell formation. New Phytol. 2020, 229, 3408-3423. [CrossRef]

30. Truong, N.M.; Chen, Y.; Mejias, J.; Soulé, S.; Mulet, K.; Jaouannet, M.; Jaubert-Possamai, S.; Sawa, S.; Abad, P.; Favery, B.; et al. The Meloidogyne incognita Nuclear Effector MiEFF1 Interacts With Arabidopsis Cytosolic Glyceraldehyde-3-Phosphate Dehydrogenases to Promote Parasitism. Front. Plant Sci. 2021, 12, 633. [CrossRef]

31. Zhao, J.; Li, L.; Liu, Q.; Liu, P.; Li, S.; Yang, D.; Chen, Y.; Pagnotta, S.; Favery, B.; Abad, P.; et al. A MIF-like effector suppresses plant immunity and facilitates nematode parasitism by interacting with plant annexins. J. Exp. Bot. 2019, 70, 5943-5958. [CrossRef]

32. Shi, Q.; Mao, Z.; Zhang, X.; Ling, J.; Lin, R.; Zhang, X.; Liu, R.; Wang, Y.; Yang, Y.; Cheng, X.; et al. The Novel Secreted Meloidogyne incognita Effector MiISE6 Targets the Host Nucleus and Facilitates Parasitism in Arabidopsis. Front. Plant Sci. $2018,9,252$. [CrossRef]

33. Godinho Mendes, R.A.; Basso, M.F.; Paes de Melo, B.; Ribeiro, T.P.; Lima, R.N.; Fernandes de Araújo, J.; Grossi-de-Sa, M.; da Silva Mattos, V.; Togawa, R.C.; Saliba Albuquerque, É.V.; et al. The Mi-EFF1/Minc17998 effector interacts with the soybean GmHub6 protein to promote host plant parasitism by Meloidogyne incognita. Physiol. Mol. Plant Pathol. 2021, 114, 101630. [CrossRef]

34. Jones, J.D.G.; Dangl, J.L. The plant immune system. Nature 2006, 444, 323-329. [CrossRef] [PubMed] 
35. Thomma, B.; Nürnberger, T.; Joosten, M.H.A.J. Of PAMPs and effectors: The blurred PTI-ETI dichotomy. Plant Cell 2010, 23, 4-15. [CrossRef] [PubMed]

36. Castel, B.; Ngou, P.M.; Cevik, V.; Redkar, A.; Kim, D.S.; Yang, Y.; Ding, P.; Jones, J.D.G. Diverse NLR immune receptors activate defence via the RPW8-NLR NRG1. New Phytol. 2019, 222, 966-980. [CrossRef] [PubMed]

37. Singh, R.; Dangol, S.; Chen, Y.; Choi, J.; Cho, Y.-S.; Lee, J.-E.; Choi, M.-O.; Jwa, N.-S. Magnaporthe oryzae Effector AVR-Pii Helps to Establish Compatibility by Inhibition of the Rice NADP-Malic Enzyme Resulting in Disruption of Oxidative Burst and Host Innate Immunity. Mol. Cells 2016, 39, 426. [PubMed]

38. Qi, T.; Guo, J.; Liu, P.; He, F.; Wan, C.; Islam, M.A.; Tyler, B.; Kang, Z.; Guo, J. Stripe Rust Effector PstGSRE1 Disrupts Nuclear Localization of ROS-Promoting Transcription Factor TaLOL2 to Defeat ROS-Induced Defense in Wheat. Mol. Plant 2019, 12, 1624-1638. [CrossRef]

39. Liu, Y.; He, C. Regulation of plant reactive oxygen species (ROS) in stress responses: Learning from AtRBOHD. Plant Cell Rep. 2016, 35, 995-1007. [CrossRef]

40. Torres, M.A. ROS in biotic interactions. Physiol. Plant. 2009, 138, 414-429. [CrossRef]

41. Li, Q.; Ai, G.; Shen, D.; Zou, F.; Wang, J.; Bai, T.; Chen, Y.; Li, S.; Zhang, M.; Jing, M.; et al. A Phytophthora capsici Effector Targets ACD11 Binding Partners that Regulate ROS-Mediated Defense Response in Arabidopsis. Mol. Plant 2019, 12, 565-581. [CrossRef]

42. Jwa, N.-S.; Hwang, B.K. Convergent Evolution of Pathogen Effectors toward Reactive Oxygen Species Signaling Networks in Plants. Front. Plant Sci. 2017, 8, 1687. [CrossRef]

43. Ali, M.; Cheng, Z.; Ahmad, H.; Hayat, S. Reactive oxygen species (ROS) as defenses against a broad range of plant fungal infections and case study on ROS employed by crops against Verticillium dahliae wilts. J. Plant Interact. 2018, 13, 353-363. [CrossRef]

44. Rice, S.L.; Leadbeater, B.S.C.; Stone, A.R. Changes in cell structure in roots of resistant potatoes parasitized by potato cystnematodes. I. Potatoes with resistance gene H1 derived from Solanum tuberosum ssp. andigenea. Physiol. Plant Pathol. 1985, 27, 219-234. [CrossRef]

45. Cai, D.; Kleine, M.; Kifle, S.; Harloff, H.-J.; Sandal Niels, N.; Marcker Kjeld, A.; Klein-Lankhorst René, M.; Salentijn Elma, M.J.; Lange, W.; Stiekema Willem, J.; et al. Positional Cloning of a Gene for Nematode Resistance in Sugar Beet. Science 1997, 275, 832-834. [CrossRef] [PubMed]

46. De Ilarduya, O.M.; Moore, A.E.; Kaloshian, I. The tomato Rme1 locus is required for Mi-1-mediated resistance to root-knot nematodes and the potato aphid. Plant J. 2001, 27, 417-425. [CrossRef]

47. Claverie, M.; Dirlewanger, E.; Bosselut, N.; Ghelder, C.; Voisin, R.; Kleinhentz, M.; Lafargue, B.; Abad, P.; Rosso, M.-N.; Chalhoub, B.; et al. The Ma Gene for Complete-Spectrum Resistance to Meloidogyne Species in Prunus Is a TNL with a Huge Repeated C-Terminal Post-LRR Region. Plant Physiol. 2011, 156, 779-792. [CrossRef]

48. Yuan, M.; Jiang, Z.; Bi, G.; Nomura, K.; Liu, M.; Wang, Y.; Cai, B.; Zhou, J.-M.; He, S.Y.; Xin, X.-F. Pattern-recognition receptors are required for NLR-mediated plant immunity. Nature 2021, 592, 105-109. [CrossRef]

49. Xiao, K.; Zhu, H.; Zhu, X.; Liu, Z.; Wang, Y.; Pu, W.; Guan, P.; Hu, J. Overexpression of PsoRPM3, an NBS-LRR gene isolated from myrobalan plum, confers resistance to Meloidogyne incognita in tobacco. Plant Mol. Biol. 2021, 107, 129-146. [CrossRef]

50. Mazo Molina, C.; Mainiero, S.; Haefner, B.; Bednarek, R.; Zhang, J.; Feder, A.; Shi, K.; Strickler, S.; Martin, G. Ptr1 evolved convergently with RPS2 and Mr5 to mediate recognition of AvrRpt2 in diverse solanaceous species. Plant J. 2020, 103, 1433-1445. [CrossRef]

51. Martin, R.; Qi, T.; Zhang, H.; Liu, F.; King, M.; Toth, C.; Nogales, E.; Staskawicz, B. Structure of the activated Roq1 resistosome directly recognizing the pathogen effector XopQ. Science 2020, 370, eabd9993. [CrossRef]

52. Toruño, T.Y.; Stergiopoulos, I.; Coaker, G. Plant-Pathogen Effectors: Cellular Probes Interfering with Plant Defenses in Spatial and Temporal Manners. Annu. Rev. Phytopathol. 2016, 54, 419-441. [CrossRef]

53. Fuller, V.L.; Lilley, C.J.; Urwin, P.E. Nematode resistance. New Phytol. 2008, 180, 27-44. [CrossRef] [PubMed]

54. Mitchum, M.G.; Hussey, R.S.; Baum, T.J.; Wang, X.; Elling, A.A.; Wubben, M.; Davis, E.L. Nematode effector proteins: An emerging paradigm of parasitism. New Phytol. 2013, 199, 879-894. [CrossRef] [PubMed]

55. Vieira, P.; Gleason, C. Plant-parasitic nematode effectors-Insights into their diversity and new tools for their identification. Curr. Opin. Plant Biol. 2019, 50, 37-43. [CrossRef] [PubMed]

56. Grynberg, P.; Togawa, R.; Freitas, L.; Antonino, J.; Rancurel, C.; Costa, M.; Grossi-de-Sá, M.; Miller, R.; Brasileiro, A.; Guimarães, P.; et al. Comparative Genomics Reveals Novel Target Genes towards Specific Control of Plant-Parasitic Nematodes. Genes 2020, 11, 1347. [CrossRef]

57. Abad, P.; Gouzy, J.; Aury, J.-M.; Castagnone-Sereno, P.; Danchin, E.G.J.; Deleury, E.; Perfus-Barbeoch, L.; Anthouard, V.; Artiguenave, F.; Blok, V.C.; et al. Genome sequence of the metazoan plant-parasitic nematode Meloidogyne incognita. Nat. Biotechnol. 2008, 26, 909-915. [CrossRef] [PubMed]

58. Baum, T.; Hussey, R.; Davis, E. Root-Knot and Cyst Nematode Parasitism Genes: The Molecular Basis of Plant Parasitism. Genet. Eng. 2007, 28, 17-43.

59. Davis, E.L.; Hussey, R.S.; Baum, T.J.; Bakker, J.; Schots, A.; Rosso, M.-N.; Abad, P. Nematode Parasitism Genes. Annu. Rev. Phytopathol. 2000, 38, 365-396. [CrossRef]

60. Davis, E.; Hussey, R.; Mitchum, M.; Baum, T. Parasitism proteins in nematode-plant interactions. Curr. Opin. Plant Biol. 2008, 11, 360-366. [CrossRef] 
61. Vieira, P.; Danchin, E.; Neveu, C.; Crozat, C.; Jaubert-Possamai, S.; Hussey, R.; Engler, G.; Abad, P.; Engler, J.; Castagnone-Sereno, P.; et al. The plant apoplasm is an important recipient compartment for nematode secreted proteins. J. Exp. Bot. 2011, 62, 1241-1253. [CrossRef]

62. Rehman, S.; Gupta, V.K.; Goyal, A.K. Identification and functional analysis of secreted effectors from phytoparasitic nematodes. BMC Microbiol. 2016, 16, 48. [CrossRef]

63. Zhao, J.; Mao, Z.; Sun, Q.; Liu, Q.; Jian, H.; Xie, B. MiMIF-2 Effector of Meloidogyne incognita Exhibited Enzyme Activities and Potential Roles in Plant Salicylic Acid Synthesis. Int. J. Mol. Sci. 2020, 21, 3507. [CrossRef]

64. Jaouannet, M.; Magliano, M.; Arguel, M.-J.; Gourgues, M.; Evangelisti, E.; Abad, P.; Rosso, M.-N. The Root-Knot Nematode Calreticulin Mi-CRT Is a Key Effector in Plant Defense Suppression. Mol. Plant-Microbe Interact. 2012, 26, 97-105. [CrossRef] [PubMed]

65. Deslandes, L.; Rivas, S. The plant cell nucleus: A true arena for the fight between plants and pathogens. Plant Signal. Behav. 2011, 6, 42-48. [CrossRef] [PubMed]

66. Motion, G.; Amaro, T.; Kulagina, N.; Huitema, E. Nuclear processes associated with plant immunity and pathogen susceptibility. Brief. Funct. Genom. 2015, 14, 243-252. [CrossRef] [PubMed]

67. Zhang, L.; Davies, L.J.; Elling, A.A. A Meloidogyne incognita effector is imported into the nucleus and exhibits transcriptional activation activity in planta. Mol. Plant Pathol. 2015, 16, 48-60. [CrossRef]

68. Huang, G.; Dong, R.; Allen, R.; Davis, E.L.; Baum, T.J.; Hussey, R.S. A Root-Knot Nematode Secretory Peptide Functions as a Ligand for a Plant Transcription Factor. Mol. Plant-Microbe Interact. 2006, 19, 463-470. [CrossRef]

69. Adamo, N.; Johnson, C.S.; Reed, T.D.; Eisenback, J.D. Reproduction of Meloidogyne arenaria race 2 on Flue-cured tobacco possessing resistance genes Rk1 and/or Rk2. J. Nematol. 2021, 53, e2021-42. [CrossRef]

70. Huang, G.; Dong, R.; Allen, R.E.X.; Davis, E.L.; Baum, T.J.; Hussey, R.S. Two chorismate mutase genes from the root-knot nematode Meloidogyne incognita. Mol. Plant Pathol. 2005, 6, 23-30. [CrossRef]

71. Xiao, K. Functional Verification and Mechanism Analysis of PsoRPM3 from Prunus sogdiana in Reponse to Meloidogyne Incognita. Ph.D. Thesis, China Agricultural University, Beijing, China, 2020.

72. Dareus, R.; Porto, A.C.M.; Bogale, M.; DiGennaro, P.; Chase, C.A.; Rios, E.F. Resistance to Meloidogyne enterolobii and Meloidogyne incognita in Cultivated and Wild Cowpea. HortScience 2021, 56, 460-468. [CrossRef]

73. Jaouannet, M.; Nguyen, C.-N.; Quentin, M.; Jaubert-Possamai, S.; Rosso, M.-N.; Favery, B. In situ Hybridization (ISH) in Preparasitic and Parasitic Stages of the Plant-parasitic Nematode Meloidogyne spp. Bio-protocol 2018, 8, e2766. [CrossRef]

74. Livak, K.J.; Schmittgen, T.D. Analysis of Relative Gene Expression Data Using Real-Time Quantitative PCR and the $2^{-\Delta \Delta C T}$ Method. Methods 2001, 25, 402-408. [CrossRef]

75. Chen, C.; Liu, S.; Liu, Q.; Niu, J.; Liu, P.; Zhao, J.; Jian, H. An ANNEXIN-Like Protein from the Cereal Cyst Nematode Heterodera avenae Suppresses Plant Defense. PLoS ONE 2015, 10, e0122256. [CrossRef] [PubMed]

76. Tran, B.Q.; Jung, S. Modulation of chloroplast components and defense responses during programmed cell death in tobacco infected with Pseudomonas syringae. Biochem. Biophys. Res. Commun. 2020, 528, 753-759. [CrossRef] [PubMed]

77. Labudda, M.; Rozanska, E.; Prabucka, B.; Muszynska, E.; Marecka, D.; Kozak, M.; Dababat, A.A.; Sobczak, M. Activity profiling of barley vacuolar processing enzymes provides new insights into the plant and cyst nematode interaction. Mol. Plant Pathol. 2020, 21, 38-52. [CrossRef] [PubMed]

78. Wang, G.-F.; Balint-Kurti, P. Maize Homologs of CCoAOMT and HCT, Two Key Enzymes in Lignin Biosynthesis, Form Complexes with the NLR Rp1 Protein to Modulate the Defense Response. Plant Physiol. 2016, 171, 2166-2177. [CrossRef] [PubMed] 